\title{
Anatomical Characteristics, Microfibril Angle and Micromechanical Properties of Cottonwood (Populus deltoides) and Its Hybrids
}

Yurong Wang ${ }^{\mathrm{a} \text { ’b }}$, Cangwei Liu ${ }^{\mathrm{a}}$, Rongjun Zhao ${ }^{\mathrm{a}}$, Jessica McCord ${ }^{\mathrm{b}}$, Tim Rials ${ }^{\mathrm{b}}$, and Siqun Wang ${ }^{* b}$

${ }^{a}$ Research Institute of Wood Industry, Chinese Academy of Forestry, Beijing, 100091, China

${ }^{\mathrm{b}}$ Center for Renewable Carbon, University of Tennessee, Knoxville, TN 37996, USA ABSTRACT:

Samples were prepared using stem xylem from cottonwood (Populus deltoides) and two cottonwood hybrids $(P$. deltoides $\times P$. maximowiczii and $P$. deltoides $\times P$. trichocarpa), which grew in Tennessee, United States. The anatomical characteristics, microfibril angle, and mechanical properties of the cell wall in juvenile wood (two-year-old) were investigated by means of microscopy image analysis system, X-ray diffraction, and nanoindentation (NI). The results showed that the double-wall thickness of the fiber cells in the hybrid poplars was thicker than that of the pure poplar, and the ratio of wall to lumen of fiber cell $(0.40)$ of the $P$. deltoides $\times P$. trichocarpa, which had the slowest growth rate, reached the greatest value among the three poplar clones. Their microfibril angles (MFA) of the cell wall in the investigated samples ranged between $11.5^{\circ}$ and $16.7^{\circ}$, and they correlated positively with growth rates of the three poplar clones. The average hardness and reduced elastic modulus 
were $0.25 \mathrm{GPa}$ and $8.58 \mathrm{GPa}$ for P. deltoides, $0.28 \mathrm{GPa}$ and $8.34 \mathrm{GPa}$ for P. deltoides $\times$ P. maximowiczii, and $0.31 \mathrm{GPa}$ and $12.2 \mathrm{GPa}$ for $P$. deltoides $\times P$. trichocarpa, respectively. P. deltoides $\times$ P.trichocarpa with the slowest growth rate had the greatest micromechanical values among the three poplar clones. In combination with growth chracteristics of the three poplar clones, the findings of the analyses on their wood properties provided information-rich data that not only could describe juvenile wood properties but also could be used in selective breeding for the three poplar clones in Tennessee, USA.

Key words: poplar, growth rate, microstructure, microfibril angle, micromechanical property

\section{Introduction:}

Poplar trees are widely planted in subtropical and temperate regions and one of the most widespread hardwood species in North America [1]. In general, the woody biomass currently available is not able to keep up with the dramatically increasing demand [2]. As short rotation woody crops (SRWCs), poplar trees, including their hybrids, have been considered as an alternative woody source and a means to meet the increasing demand due to their characteristics of fast growth and ease of reproduction [3-4]. Hybrid poplars are important components of current energy portfolios because they produce significant amount of biomass [5-7]. Furthermore, as a natural and renewable material, poplar wood has multiple purposes and can be used for pulp and paper, furniture, wood-based composites, and construction $[1,8]$.

It is critical to select superior poplar clones to increase biomass quantity and 
improve the quality of wood production. Populus deltoides Bartr. Ex Marsh, as a parent of inter-specific hybridizations in poplars, has been selected as the primary species in the north-central USA [9]. Besides $P$. deltoides, $P$. trichocarpa and $P$. maximowiczii are also valuable poplar clones and there has been some valuable research regarding their survival, growth rate, and disease resistance [10-13]. In addition, some researches have also focused on their biomass yield and it has been known that, tree height, basal area, and number of branches are all important traits for maximum biomass yield in poplars [14-15]. However, not enough is yet known about the properties of poplar wood, which remain to be assessed [16-17]. Mechanical properties of wood can provide an indication of wood quality [18-19].

Tree growth rate has a strong effect on wood properties [20]. For example, a fast growth rate correlates positively with MFA and stiffness [21-22]. The particular hybrid crosses can all significantly influence the growth and wood properties of Populus [23]. Thus, it is very important to evaluate wood properties based growth rates in different developmental stages of trees. There has been little in the literature about wood properties of hybrid poplar that indicates that inter-species crosses have more desirable wood traits than do intra-specific populous spp. crosses [24], although biomass yield and chemical composition of hybrid poplars in Minnesota, US, have been obtained [7]. So far, no report data were found evaluating morphological characteristics and microfibril angle of wood cell at the microscopic and submicroscopic levels, and mechanical properties of cell wall at the nanometer level of different hybrid poplar clones of the same parentage in Tennessee, USA. 
The objectives of the present study were to evaluate the growth rate of Populus deltoides and two of its hybrids, to observe their wood anatomy, to determine the micromechanical properties of cell walls, and then to compare the differences of growth traits and wood properties of the cell walls among the three poplar clones in their early developmental stage.

\section{Materials and methods}

\subsection{Materials}

The sample trees of $P$. deltoides, $P$. deltoides $\times$ P.maximowiczii and $P$. deltoides $\times P$. trichocarpa had been planted at the East Tennessee Research \& Education Center (ETREC) in Louisville, TN, USA. The research center is located at elevation $272 \mathrm{~m}$ and $83^{\circ} 57^{\prime}$ west longitude and $35^{\circ} 50^{\prime}$ north latitude. The average annual temperature is $15.3^{\circ} \mathrm{C}$ and the average annual precipitation is $1124 \mathrm{~mm}$.

Three sample trees of each poplar clone with a planting density of $91 \times 91 \mathrm{~cm}$ were harvested two years later. The height and diameter at breast height $1.3 \mathrm{~m}(\mathrm{DBH})$ of each sample tree were measured. As shown in Fig.1, from each sample tree, one sample disc with a thickness of $50 \mathrm{~mm}$ was sawn at breast height. The disc was sawn into two strips at pith. From Strip 1, $1.5 \times 10 \mathrm{~mm}($ radial $[\mathrm{R}] \times$ tangential $[\mathrm{T}])$ slices were continuously cut from pith to bark and 3-5 slices were obtained to determine the average MFA by X-ray diffraction (XRD). Smaller sticks were then cut from Strip 1 and made into a rectangular pyramid at the top of the stick for testing micromechanics by the nanoindentation $(\mathrm{NI})$ method. A $10 \times 10 \mathrm{~mm}($ tangential $[\mathrm{T}] \times$ longitudinal $[\mathrm{L}])$ wood block was from Strip 2 and was used for anatomical analysis. 


\subsection{Anatomical characteristics analysis}

In order to observe the morphological properties of the cells in the three poplar clones, wood blocks were also sectioned at a thickness of $15 \mu \mathrm{m}$ using a sliding microtome, after which the sections were dehydrated through an alcohol series and stained with safranine. The microstructures of the poplars were observed and their double cell wall thicknesses and cell lumen diameters were measured using a Leica DMLB light microscope and an image analysis system (Japan, Q570).

\subsection{MFA determination}

An X-ray diffractometer (Panalytical X'Pert Pro, Netherlands) was used to measure the MFA of poplar samples with a sample size of $1.5 \times 10 \mathrm{~mm}(\mathrm{R} \times \mathrm{T})$. Each wood sample was attached to a holder with a hole $(2 \times 4 \mathrm{~mm})$ that held the wood sample perpendicular to the incident X-ray beam. The beam passed through the tangential face of the sample, and the angle between the receiving optical path and the incident ray was $22.4^{\circ}$. The scanning step was $0.5^{\circ}$ and the angle of rotation was $0-360^{\circ}$. The curve was obtained from 002 face diffraction with the strongest diffraction intensity. Mean MFAs were calculated according to the method developed by Cave and Meylan; that is, $0.6 \mathrm{~T}$ of parameter $\mathrm{T}$ was taken from tangents drawn at the points of inflection [25-27].

\subsection{Nanoindentation test}

Nanoindentation (NI) was used to obtain the modulus and hardness values of the wood cell wall. The samples for NI were taken from the samples were measured MFA (Fig.1) and the size was $1.5 \times 3 \times 3 \mathrm{~mm}(\mathrm{R} \times \mathrm{T} \times \mathrm{L})$. The specimens were tested on a 
Hysitron TriboIndenter system (Hysitron Inc., USA) with scanning probe microscopy and Berkovich indenter. Experiments were performed in load-controlled mode using a pre-force of $0.1 \mu \mathrm{N}$ and a three-segment load ramp (loading/holding/unloading in $5 \mathrm{~s} / 5 \mathrm{~s} / 5 \mathrm{~s})$. The peak load was $150 \mu \mathrm{N}$ for all indents in the experiment. The hardness and reduced modulus of elasticity were calculated based on the Oliver and Pharr method [28] by using the load-displacement data from the NI tests.

\section{Results and discussion}

\subsection{Growth rate}

All of the sample trees of $P$. deltoides (clone No. 185), P. deltoides $\times P$. maximowiczii (clone No. 230) and P. deltoides $\times$ P. trichocarpa (clone No. 303) were two years old. The sample trees of $P$. deltoides, $P$. deltoides $\times P$. maximowiczii and $P$. deltoides $\times P$. trichocarpa had an average annual increase in height of $2.72 \mathrm{~m}, 2.73 \mathrm{~m}$ and $2.56 \mathrm{~m}$, respectively; an average annual increase in diameter at breast height (DBH) of 2.97 $\mathrm{cm}, 3.47 \mathrm{~cm}$, and $2.61 \mathrm{~cm}$ respectively.

These poplar trees had the higher growth rates and more obvious characteristics of fast growth than other poplar trees [16-17]. Site can significantly influence growth traits of Populus [23], and therefore comparison of growth rate was carried out among the different clones of poplars from the same site. It showed from the comparison that P. deltoides $\times P$. maximowiczii grew fastestly and $P$. deltoides $\times P$. trichocarpa grew slowestly among the three poplar clones.

\subsection{Anatomical characteristics of cell in poplar woods}

As shown in Fig.2, there were some differences in the transition from earlywood to 
latewood in the different poplar clones at the early developmental stage. A clear boundary line of annual rings could be seen in P. deltoides, but it was difficult to discern the boundary line of annual rings in its hybrids.

The anatomical parameters and their statistical analyses of the three poplar clones were listed in Table 1 and Table 2 . The each mean value was from almost 100 fiber cells or 60 vessels of each poplar clone. Their average double cell wall thickness of the fiber varied from $3.93 \mu \mathrm{m}$ to $5.32 \mu \mathrm{m}$. It can be seen that the mean values of fiber cell wall thickness thickened with hybridization $(P$. deltoides $\times$ P. maximowiczii, P.deltoides $\times$ P. trichocarpa). The fiber cell thickness of these hybrids poplar was similar with that of the second ring of the five-year-old Populus $\times$ euramericana (17). The diameters of the fiber lumen were approximately equal between $P$. deltoides and $P$. deltoides $\times P$. maximowiczii, whereas it significantly declined in $P$. deltoides $\times P$. trichocarpa (Table 1). The ratio of fiber cell wall to cell lumen was $0.24,0.32$ and 0.40 among $P$. deltoides, $P$. deltoides $\times P$. maximowiczii and $P$. deltoides $\times P$. trichocarpa, respectively.

The mean value of the vessel cell thickness had no distinction, ranging from 3.35 to $3.82 \mu \mathrm{m}$, while the vessel lumens diameter of hybrid poplars decreased when contrasted to that of the pure poplar (Table 1), indicating that hybridization impacts the vessel lumen size. The ratio of double wall value to lumen was increased after hybridization due to the cell wall thickening or reducing the size of the fiber lumen in hybrid poplars. The ratio of vessel cell wall to lumen varied from 0.05 to 0.07 among the three poplar clones. 


\subsection{MFA of cell wall in poplar woods}

There are 10-15 slices of each poplar clone were determined to obtain the value of MFA. X-ray diffraction spectra of the three clones of poplar sample slices were presented in Fig.3. The full width at half maximum (FWHM) of spectrum corresponds to the MFA value. The $14.1^{\circ}, 16.7^{\circ}$ and $11.5^{\circ}$ were the mean MFA values of $P$. deltoides, P.deltoides $\times$ P.maximowiczii and P.deltoides $\times$ P.trichocarpa, respectively. The mean values of the MFA among the three poplar clones show significant differences (Table 3). The mean MFA of the 2-year-old P. deltoides $\times$ P.trichocarpa around $12^{\circ}$ is close to that in mature Populus wood from trees more than 15 years old [29]. P. deltoides $\times$ P. maximowiczii grew fastest and had the largest MFA in the cell walls, while, $P$. deltoides $\times P$. trichocarpa grew slowest and had the smallest MFA in the cell walls, echoing the findings of Herman, who also found that fast-growing spruces had larger MFAs compared with spruces that grew at a slower rate [30].

The MFA was affected not only by the influence of genetic characteristics, but also by the growth environment and the supply of nutrition [31]. These sample trees came from the same site and had no different supplies of nutrition, so the differences in their MFAs indicate that hybridization affected the orientation of the microfibril of the $\mathrm{S}_{2}$ layer of the cell wall. MFA plays an important role in the axial strength, longitudinal elastic modulus, and longitudinal shrinkage of fiber cells and shows a negative correlation with mechanical properties [32-33]. Consequently, sometime the MFA values reveal the mechanical characteristic of the specimens.

\subsection{Mechanical properties of the cell wall in poplar woods}


The top surfaces of solid woods were polished with a diamond knife and the image of the microstructure of sample was obtained using the microscope of the NI instrument (Fig. 4). The test fiber cells were selected based on the image and clear cell wall which could be seen with scanning probe microscopy (Fig. 5). It was difficult to get valid micromechanics values due to the thinner cell walls of poplar woods in the early developmental stage. As shown in Fig.5, the valid indentation points were only numbers 4, 5 and 11. Many cell walls need to be tested in order to analyze the micromechanical properties of poplar woods. Finally almost 35 valid points of each poplar sample tree were selected to obtain the micromechanical properties.

The reduced elastic modulus (Er), hardness (Hd) and their statistical analysis of juvenile woods of the three clones of poplars were presented in Table 4. The larger hardness had been found in hybrid poplars and the reduced elastic modulus (12.2GPa) and hardness value $(0.31 \mathrm{GPa})$ of $P$. deltoides $\times P$. trichocarpa was greatest and showed significant difference with another two poplar clones (Table 4). The hardness showed significant difference among the three poplar clones. The reduced elastic moduli showed no significant difference between $P$. deltoides and $P$. deltoides $\times P$. maximowiczii. They also had different load-displacement curves among the three poplar clones (Fig.6), and there was shallowest depth of indentation in P. deltoides $\times P$. trichocarpa. The mean reduced elastic moduli of juvenile wood cell walls of the three kinds of poplar were similar to the macromechanical properties of 5-year-old Populus $\times$ euramericana and smaller than micromechanical properties of 16-year-old mature poplar $[17,34]$ 


\section{Conclusions}

Despite having the same male parent and being grown in the same location, Populus deltoides and its hybrids, $P$. deltoides $\times P$. maximowiczii and $P$. deltoides $\times P$. trichocarpa, had distinct performances in growth, anatomy and micromechanics during their early developmental stage. The double-wall thickness of the fiber cells in the hybrid poplars was thicker than that of the pure poplar. The ratio of wall to lumen of fiber cell (0.40) in $P$. deltoides $\times P$. trichocarpa with the slowest growth rate was biggest and it also had the smallest MFA $\left(11.5^{\circ}\right)$, which may contribute to its greatest micromechanics value of hardness and reduced elastic modulus $(0.31 \mathrm{GPa}$ and $12.2 \mathrm{GPa})$ among the three poplar clones. The $P$. deltoides $\times P$. maximowiczii with the fastest growth rate had the largest MFA $\left(16.7^{\circ}\right)$ among the three poplar clones and had similar micromechanics values of reduced elastic modulus with $P$. deltoids, however it had bigger ratio of wall to lumen of fiber cell and larger hardness than that of $P$. deltoids.

\section{Acknowledgment}

The authors would like to gratefully acknowledge financial support from the Chinese National Natural Science Foundation (No. 31370562), the China Scholarship Council (CSC), from the Agriculture and Food Research Initiative Competitive Grant (2011-68005-30410), the USDA National Institute of Food and Agriculture, and the State Key Laboratory of the Chinese Academy of Forestry Foundation (CAFYBB2012044). Thanks also go to the following: Mr. Xinzhou Wang of the Center for Renewable Carbon (CRC) for the technical help regarding the nanoindentation test, Mr. Lichao Jiao of Research Institute of Wood Industry, Chinese 
Academy of Forestry for the technical help regarding the microstructure observation, Ms. Anna Kim and Ms. Choo Hamilton of CRC of the Univ. of Tennessee for sample sawing.

\section{References}

[1] Balatinecz JJ, Kretschmann DE. Poplar culture in North America. A publication of the National Research Council of Canada monograph publishing program. 9th ed, Properties and utilization of poplar wood 2001; 277-91.

[2] Fenning TM, Gershenzon J. Where will the wood come from? Plantation forests and the role of biotechnology. Trends Biotech 2002; 20:291-96.

[3] Koubaa A, Hernández RE, Beaudoin M, Poliquin J. Interclonal, intraclonal, and within-tree variation in fiber length of poplar hybrid clones. Wood Fiber Sci 1998; 30: 40-7.

[4] Pitre FE, Cooke,JEK, Mackay JJ. Short-term effects of nitrogen availability on wood formation and fibre properties in hybrid poplar. Trees 2007; 21(2): 249-59.

[5] Johnson JMF, Coleman MD, Gesch R, Jaradat A, Mitchell R, Reicosky D et al. Biomass-bioenergy crops in the United States: A changing paradigm. Am J Plant Sci Biotechnol 2007; 1(1): 1-28.

[6] Langholtz M, Graham R, Eaton L, Perlack R, Hellwinkel C et al. Price projections of feedstocks for biofuels and biopower in the U.S. Energy Pol 2012; 41: 484-93.

[7] Zamora DS, Wyatt GJ, Apostol GK, Tschirner U. Biomass yield, energy values, and chemical composition of hybrid poplars in short rotation woody crop production and native perennial grasses in Minnesota, USA. Biomass and bioenergy 2013; 49: 222-30.

[8] Ding W, Ahmed K, Abdelkader C. Mechanical properties of MMA-hardened hybrid poplar 
wood. Industrial Crops and Products 2013; 46: 304-10.

[9] Riemenschneider DE, Berguson WE, Dickmann DI, Hall RB, Isebrands JG et al. Poplar breeding and testing strategies in the north-central U.S.: Demonstration of potential yield and consideration of future research needs. For. Chron 2011; 77: 245-53.

[10] Lo MH, Lawence PA. Principal component analysis to evaluate the relative performance of nine year old hybrid poplar clones. Biomass and bioenergy 1996; 10: 1-6.

[11] Guo X, Zhang X. Performance of 14 hybrid poplar clones grown in Beijing, China. Biomass and bioenergy 2010; 34: 909-11.

[12] Pliura A, Zhang S, Mackay J, Bousquet J. Genotypic variation in wood density and growth traits of poplar hybrids at four clonal trials. Forest Ecology and Management 2007; 238: 92-106.

[13] Gong J, Zhang X, Huang Y. Comparison of the performance of several hybrid poplar clones and their potential suitability for use in northern China. Biomass and bioenergy 2011; 35: 2755-64.

[14] Fortier J, Gagnon D, Truax B, Lambert F. Biomass and volume yield after 6 years in multiclonal hybrid poplar riparian buffer strips. Biomass and bioenergy 2010; 34: 1028-40.

[15] Fang S, Zhai X, Wan J, Tang L. Clonal variation in growth, chemistry and calorific value of new poplar hybrids at nursery stage. Biomass and bioenergy 2013; 54: 303-11.

[16] Tian X, Xie J, Qu L, Liu S, Li J et al. Growth and wood property of Poplar 741. Scientia Silvae Sinicae 2013; 49: 129-35.

[17] Zhao R, Yao C, Cheng X, Lu J, Fei B, Wang Y. Anatomical, chemical and mechanical properties of fast-growing Populus $\times$ euramericana cv. '74/76'. IAWAI Journal 2014; 35(3): $158-69$. 
[18] Longui EL, Brémaud I, Júnior FJDC, Lombardi DR, Alves ES. Relationship among extractives, lignin and holocellulose contents with performance index of seven wood species used for bows of string instruments. IAWA 2012; 33: 141-49.

[19] Yu Q, Zhang S, Pliura A, Mackey J, Bousquet J, Périnet P. Variation in mechanical properties of selected young poplar hybrid crosses. Forest Science 2008, 54(3): 255-59.

[20] Fang C, Guibal D, Clair B, Gril J, Liu Y \& Liu S. Relationships between growth stress and wood properties in poplar I-69 (Populus deltoides Bartr. cv. "Lux" ex I-69/55). Ann. For. Sci. 2008, 65: 307-16.

[21] Cave ID, Walker JCF. Stiffness of wood in fast-grown plantation softwoods: the influence of microfibril angle. Forest Prod 1994; 44: 43-8.

[22] Lindstrom H, Evans JW, Verrill SP. Influence of cambial age and growth conditions on microfibril angle in young Norway spruce. Holzforschung 1998; 52: 573-81.

[23] Monteoliva S, Senisterra G. Site, hybrid crosses and clone effect on growth and wood properties of Populus. Invest. Agrar. Sist. Recur. For 2008; 17: 261-70.

[24] Hart JF, Araujo FD, Thomas BR, Mansfield SD. Wood Quality and Growth Characterization across Intra- and Inter-Specific Hybrid Aspen Clones. Forests, 2013, 4: 786-807.

[25] Cave ID. Theory of X-ray measurement of microfibril angle in wood. Forest Prod 1966; 16 : $37-42$.

[26] Meylan BA. Measurement of microfibril angle by X-ray diffraction. Forest Prod 1967; 17: $51-8$.

[27] Andersson S, Serimaa R, Torkkeli M, Paakkari T, Saranpää P, Pesonen E. Microfibril angle of Norway spruce compression wood: Comparison of measuring techniques. J. Wood Sci 2000; 46: 
$343-9$.

[28] Oliver WC, Pharr G. An improved technique for determining hardness and elastic modulus using load and displacement sensing indentation experiments. J Mater Res 1992; 7(6): 1564-83.

[29] Fang S, Yang W \& FU X. Variation of microfibril angle and its correlation to wood properties in poplars. J. Forest. Res 2004; 15: 261-7.

[30] Herman M, Dutilleul P, Avella-Shaw T. Growth rate effects on intra-ring and inter-ring trajectories of microfibril angle in Norway spruce (Picea abies). IAWA Journal 1999; 20(1): 3-21. [31] Donaldsom L. Microfibril angle: measurement, variation and relationships: A review. IAWA 2008; 29: 345-86.

[32] Lachenbruch B, Johnson GR, Downes GM, Evans R. Relationships of density, microfibril angle, and sound velocity with stiffness and strength in mature wood of Douglas-fir. Canadian Journal of Forest Research 2010; 10: 55-64.

[33] Yin Y, Bian M, Song K, Xiao F, Jiang X. Influence of microfibril angle on within-tree variations in the mechanical properties of Chinese fir (Cunninghamia lanceolata). IAWA J 2011; 32: $431-42$.

[34] Wu Y, Wang S, Zhou D, Xing C, Zhang Y. Use of nanoindentation and silviscan to determine the mechanical properties of 10 hardwood species. Wood science and Technology 2009; 41(1):64-73. 


\section{Figures and Tables:}

Table 1 The anatomical parameters of the three poplar clones.

Table 2 Variance analysis of anatomical parameters of the three poplar clones.

Table 3 The mean value and variance analysis of MFA of the three poplar clones.

Table 4 The mean value and variance analysis of micromechanical properties of the three poplar clones.

Fig. 1 Poplar trees and preparation of poplar wood samples.

Fig. 2 Cross-sectional microphotographs of three poplar clones. Note: P. deltoides (clone No.185),

P. deltoides $\times$ P.maximowiczii (clone No. 230) and P. deltoides $\times$ P.trichocarpa (clone No. 303).

The numbers, 185, 230 and 303, represent the clone number of the three poplar clones in the figures and tables.

Fig. 3 X-ray diffraction spectrum during MFA test of the three poplar clones.

Fig. 4 Cross-sectional microstructure of solid poplar wood polished with a diamond knife.

Fig. 5 Image of fiber cell wall with scanning probe microscopy after indentation.

Fig. 6 Typical NI load-displacement curves of the three poplar clones. 
Table 1

\begin{tabular}{lccc}
\hline & 185 & 230 & 303 \\
\hline FT $(\mu \mathbf{m})$ & $3.93 \pm 0.55$ & $5.32 \pm 0.58$ & $5.23 \pm 0.57$ \\
FD $(\mu \mathbf{m})$ & $16.7 \pm 1.86$ & $16.7 \pm 2.0$ & $13.0 \pm 1.3$ \\
FR & 0.24 & 0.32 & 0.40 \\
VT' $(\mu \mathbf{m})$ & $3.35 \pm 0.47$ & $3.78 \pm 0.54$ & $3.82 \pm 0.54$ \\
VD $(\mu \mathbf{m})$ & $64.8 \pm 8.7$ & $54.8 \pm 7.1$ & $51.6 \pm 6.4$ \\
VR & 0.05 & 0.07 & 0.07 \\
\hline
\end{tabular}

* P. deltoides (clone No.185), P. deltoides $\times$ P.maximowiczii (clone No. 230) and P. deltoides $\times$ P.trichocarpa (clone No. 303). FT, double thickness of fiber cell wall; FD, diameter of fiber cell lumen; FR, the ratio of fiber cell wall thickness to cell lumen; VT, vessel wall thickness; VD, diameter of vessel cell lumen; VR, the ratio of vessel cell wall thickness to vessel lumen.

Table 2

\begin{tabular}{ccccc}
\hline & FT & FD & VT & VD \\
\hline 185 & A & A & A & A \\
230 & B & A & B & B \\
303 & B & B & B & B \\
P & $2.95 E-33$ & $4.79 E-34$ & $5.90 \mathrm{E}-08$ & $4.27 \mathrm{E}-23$ \\
\hline
\end{tabular}

${ }^{*} \mathbf{P}$ is the analysis of variance among the three poplar clones, there is significant difference, if $\mathbf{P}<0.05$. 
Table 3

\begin{tabular}{ccccc}
\hline & 185 & 230 & 303 & $\mathrm{P}$ \\
\hline Mean & $14.1^{\circ} \pm 2.12$ & $16.7^{\circ} \pm 1.34$ & $11.5^{\circ} \pm 3.52$ & 0.0000809 \\
Value & $\mathrm{A}$ & $\mathrm{B}$ & $\mathrm{C}$ & \\
\hline
\end{tabular}

${ }^{*} \mathbf{P}$ is the analysis of variance among the three poplar clones, there is significant difference, if $\mathbf{P}<0.05$. 
Table 4

\begin{tabular}{ccccc}
\hline & $\mathrm{Er}(\mathrm{GPa})$ & & $\mathrm{Hd}(\mathrm{GPa})$ & \\
\hline 185 & $8.58 \pm 0.83$ & $\mathrm{~A}$ & $0.25 \pm 0.03$ & $\mathrm{~A}$ \\
230 & $8.34 \pm 1.38$ & $\mathrm{~A}$ & $0.28 \pm 0.04$ & $\mathrm{~B}$ \\
303 & $12.2 \pm 1.25$ & $\mathrm{~B}$ & $0.31 \pm 0.03$ & $\mathrm{C}$ \\
$\mathrm{P}$ & $5.50 \mathrm{E}-25$ & & $6.31 \mathrm{E}-10$ & \\
\hline
\end{tabular}

*Er, reduced elastic modulus; Hd, hardness. $\mathbf{P}$ is the analysis of variance among the three poplar clones, there is significant difference, if $\mathbf{P}<0.05$. 

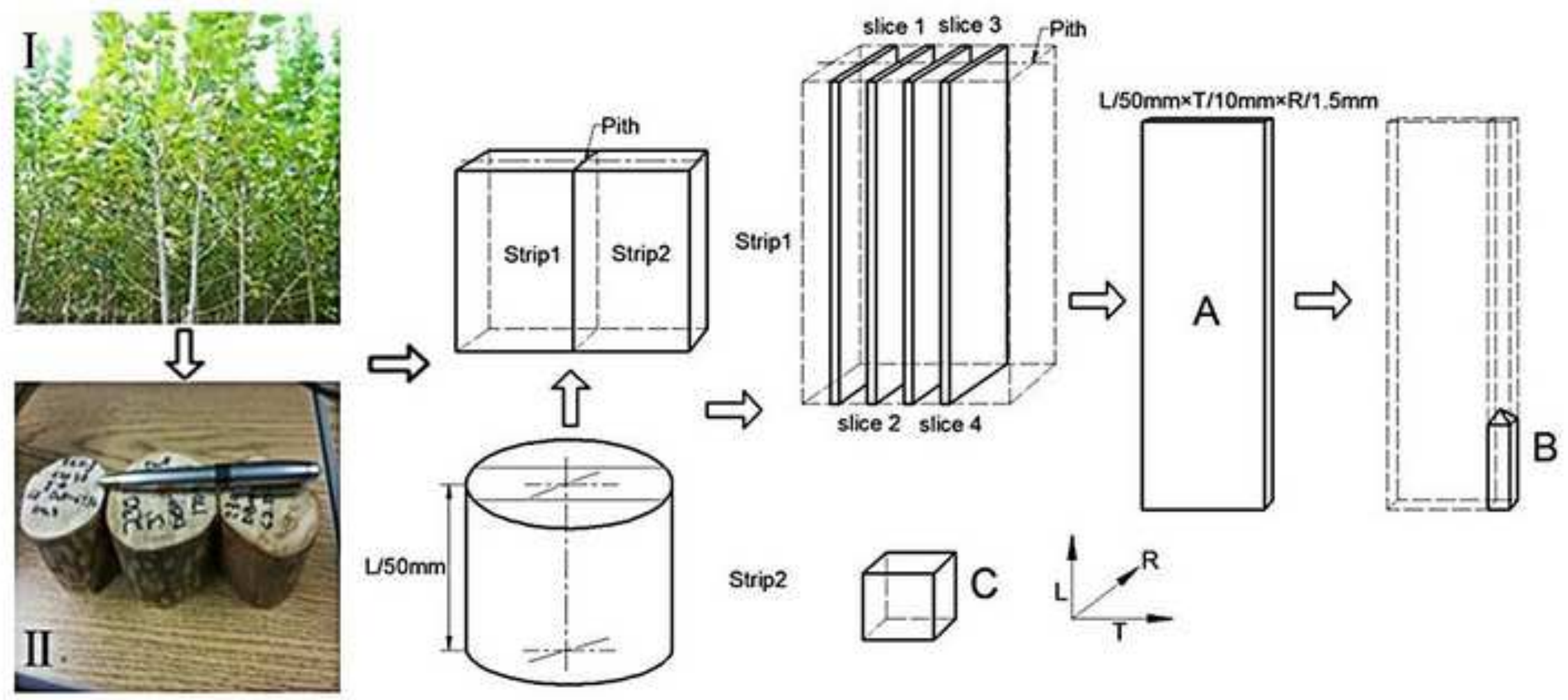

\section{I - Poplar trees' observed growth traits}

II - Wood properties of the discs studied.
A - MFA sample
$50 \mathrm{~mm}(\mathrm{~L}) \times 10 \mathrm{~mm}(\mathrm{~T}) \times 1.5 \mathrm{~mm}(\mathrm{R})$
B - Nanoindentation sample
$3 \mathrm{~mm}(\mathrm{~L}) \times 3 \mathrm{~mm}(\mathrm{~T}) \times 1.5 \mathrm{~mm}(\mathrm{R})$
C - Anatomical sample
$10 \mathrm{~mm}(\mathrm{~L}) \times 10 \mathrm{~mm}(\mathrm{~T})$. 

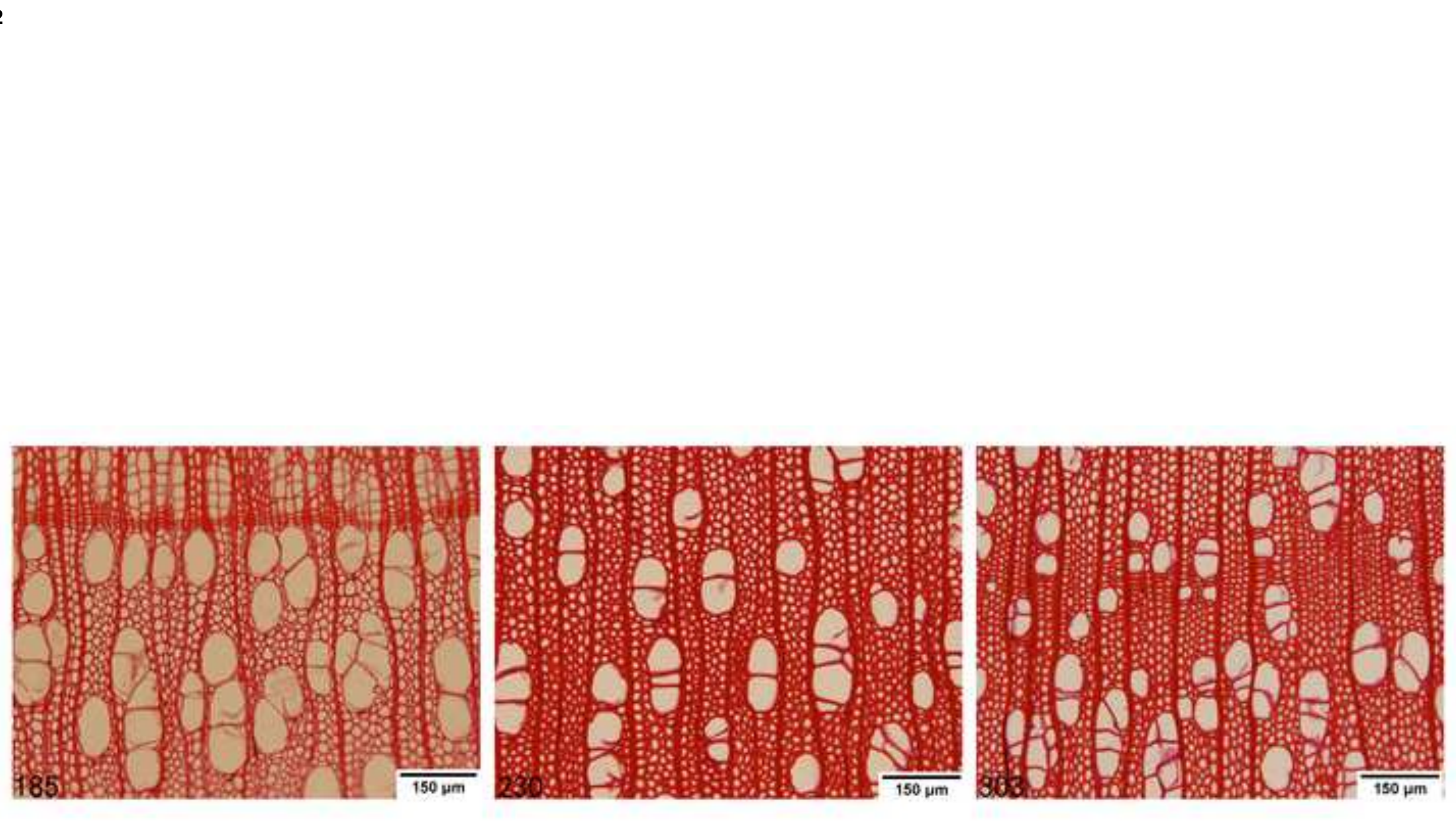


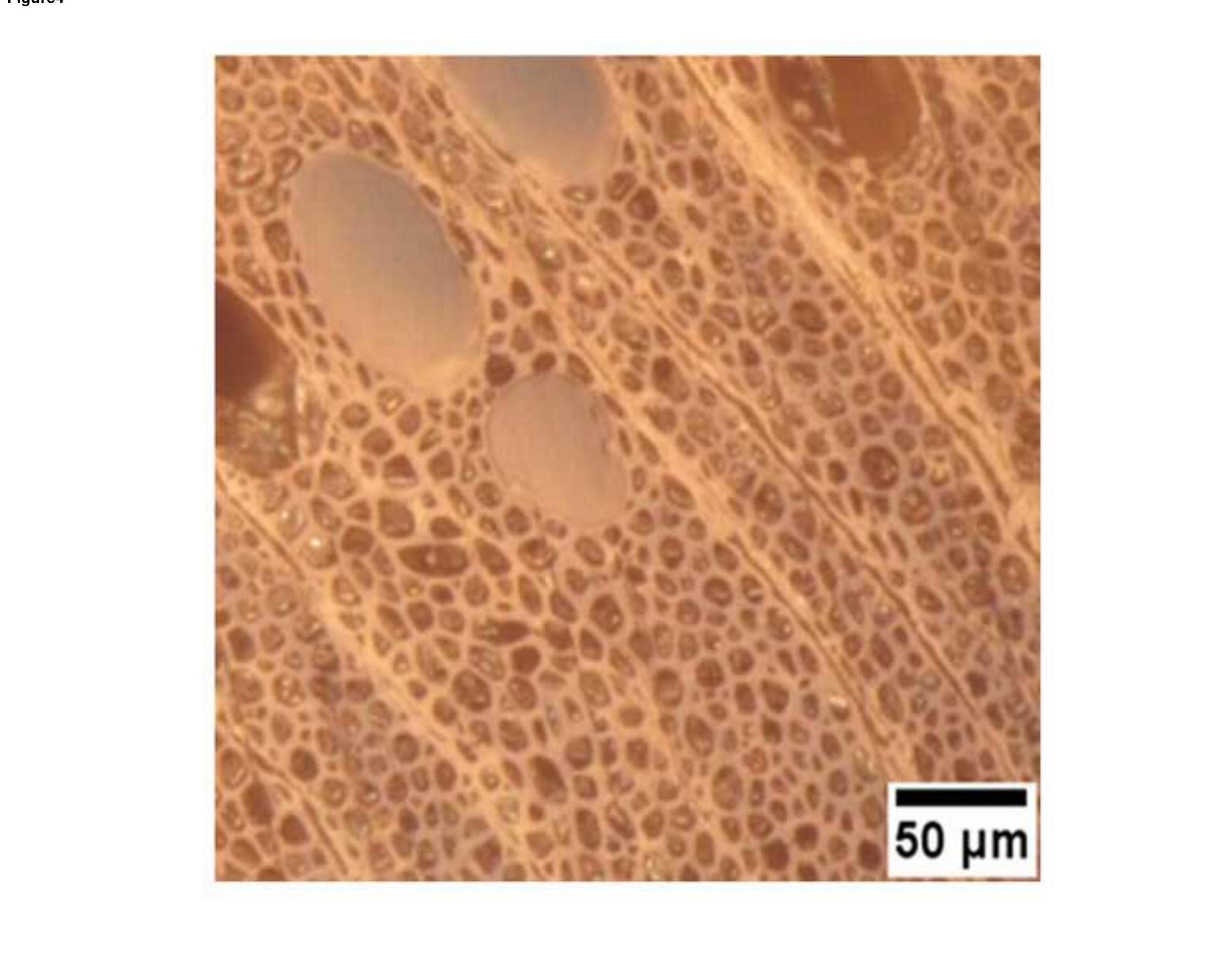

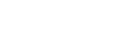

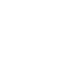
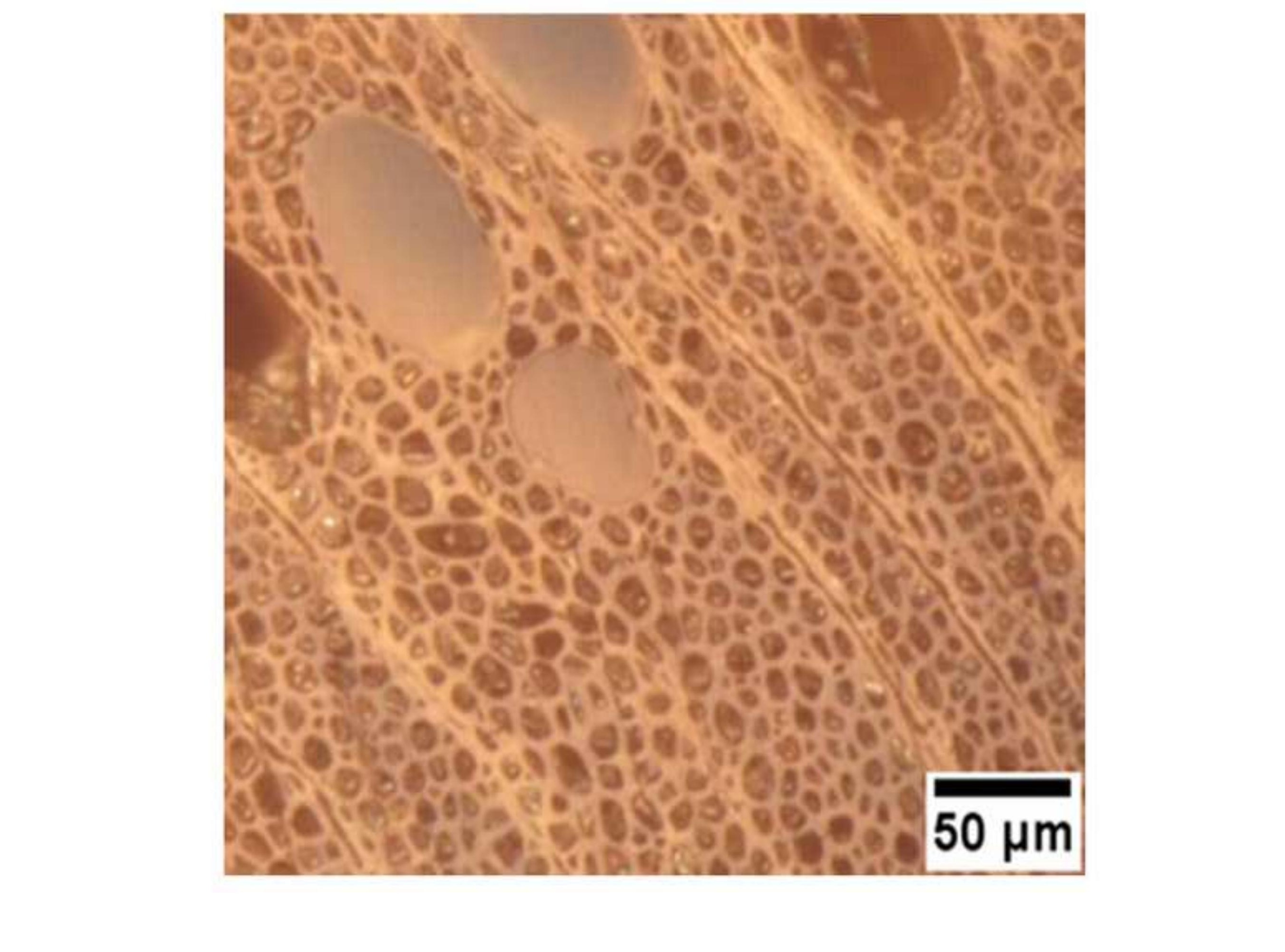

$50 \mu$
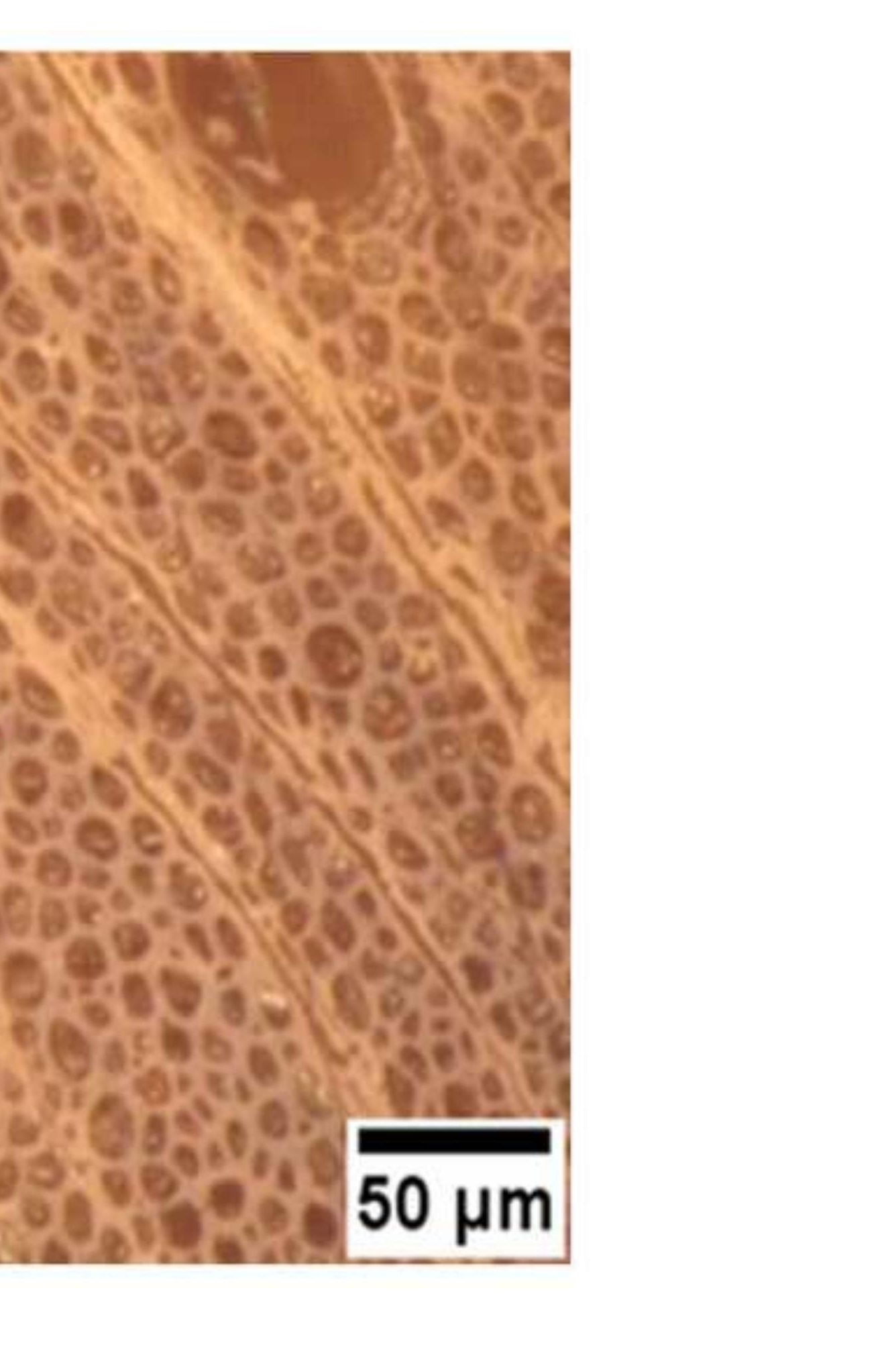
Figure5

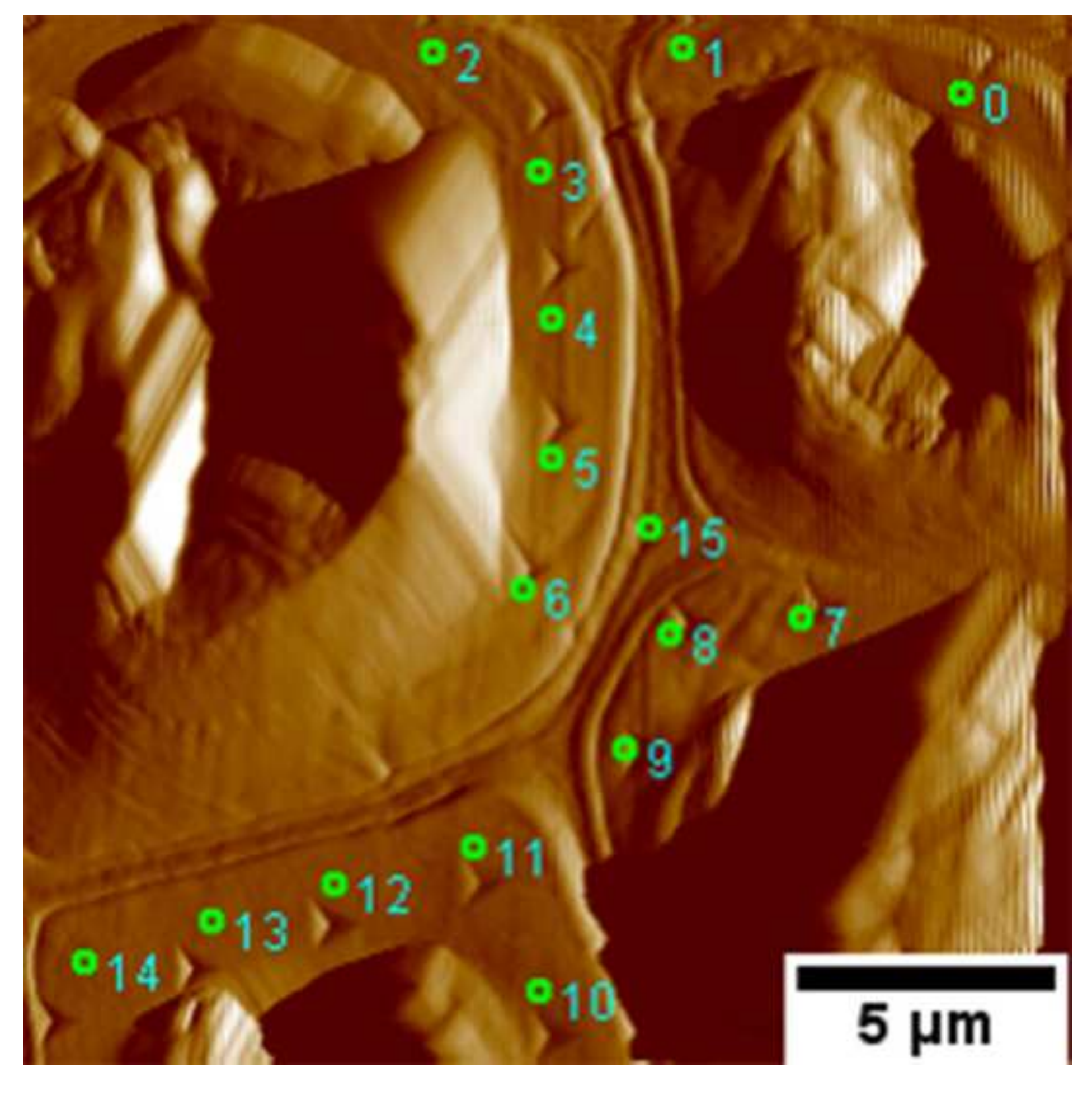

.

(1)

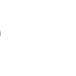

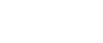
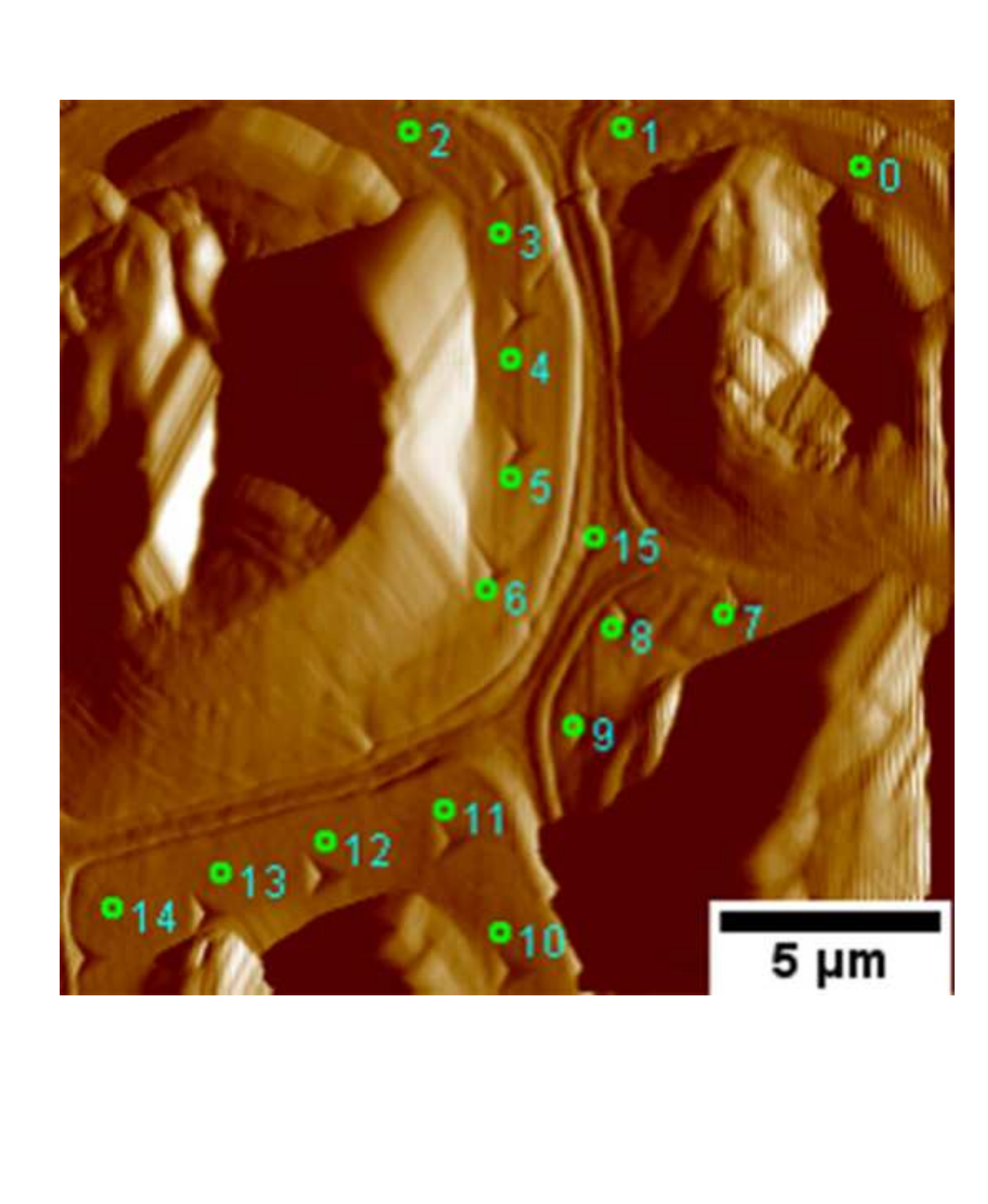

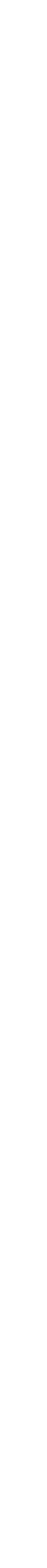

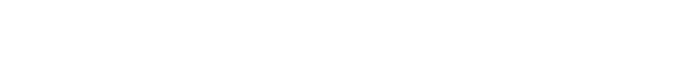

-

$-\frac{1}{2}$

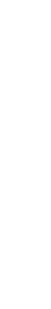

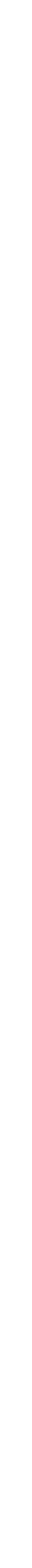

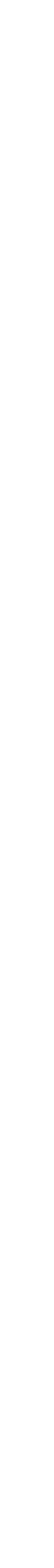




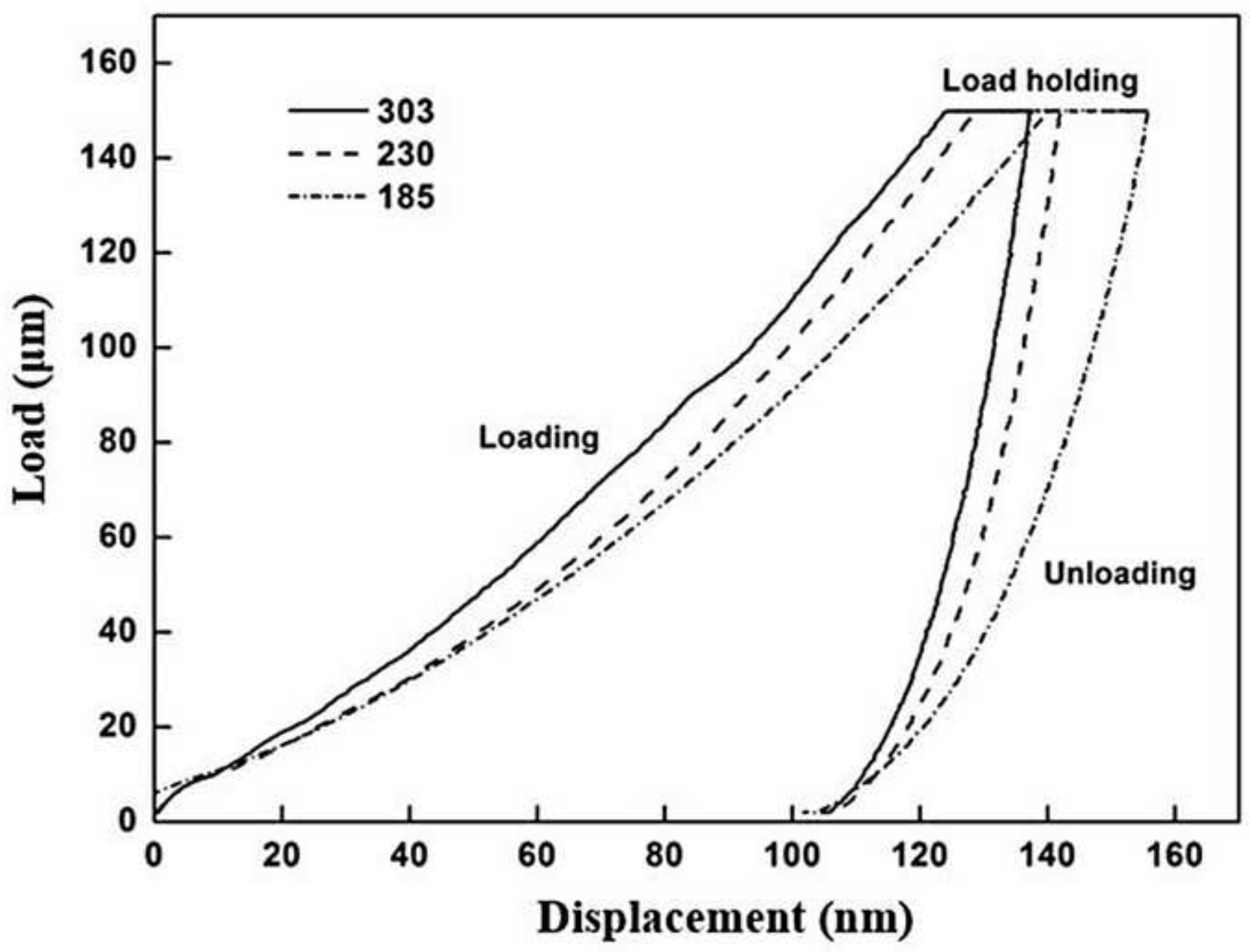

